\title{
Bacteriology and Qualitative Study of African Locust Bean (Parkia biglobosa)
}

\author{
Olajide Adedayo Ajayi \\ Department of Microbiology, Adekunle Ajasin University, Akungba-Akoko, Nigeria \\ Email: jidet02@yahoo.com
}

Received June 2014

\begin{abstract}
This study helps to determine the microbiological quality of local fermented food condiment, African locust bean (Parkia biglobosa) obtained from Ondo State, Nigeria. Bacterial species encountered during the study ranged from $20 \times 10^{3} \mathrm{cfu} / \mathrm{g}$ to $200 \times 10^{3} \mathrm{cfu} / \mathrm{g}$ for total bacterial count, $3 \times 10^{3} \mathrm{cfu} / \mathrm{g}$ to $120 \times 10^{3} \mathrm{cfu} / \mathrm{g}$ for coliform count and $1 \times 10^{3} \mathrm{cfu} / \mathrm{g}$ to $60 \times 10^{3} \mathrm{cfu} / \mathrm{g}$ for the Lactobacillus spp. in MRS agar. Some physical sensory study shows that odour became more pleasant when fermentation process take place for longer days and became slimy when fermentation continued at the day four. Adverse changes in this product such as the colour commences after 96 hours. Common bacterial species that persistently populate the samples includes Bacillus spp., Lueconostoc spp. and Staphylococcus spp. The Lueconostoc spp. only survives till the second day of fermentation as distinct from others which are still found after the seventh (7) day. This study helps in the investigation of microbiological hazards associated with fermented locust beans in order to safeguard the production of this food condiment meant for human consumption.
\end{abstract}

\section{Keywords}

Bacteriology, Fermentation, Food Condiment, Parkia biglobosa, Nigeria

\section{Introduction}

African locust bean (Parkia biglobosa) is a nutritious source of food since it is rich in protein and some beneficial health components. It will serve as a cheap source of protein for most of the people whose protein intake is low due to high costs of animal protein sources. Previous studies [1]-[4] show that locust bean is highly digestible $(74 \%-97 \%)$ with pepsin followed by trypsin. This is coupled with its high commercial values as food and medicinal agent [5] [6]. Lipolysis and proteolysis are very important for the quality of African locust bean-based condiments fermented by Bacillus spp. [5] [7]. Proteolysis has been reported as the main metabolic activity during the fermentation of African locust bean [8] [9]. The fermentation of seeds of Parkia clappertoniana keay (also known as African locust bean tree) results in the production of a delicious food spice called "iru" in Nigeria. There are two types of "iru”, "iru woro" (harder fermented product) and "iru pete" (the softer and pastier product with mashed cotyledons) which is the fermented form. The spice also thickens and adds flavor to soup. Traditionally, Parkia biglobosa are usually prepared by boiling for 8 - 12 hours depending on the strength of the testa and on the de-hulling efficiency of the seeds. Boiling in $0.1 \mathrm{M} \mathrm{Na}_{2} \mathrm{CO}_{3}$ reduces the cooking time to 4 hours 
and increases the de-hulling efficiency to $80 \%$ [10]. It can be mashed with bare feet or in a mortar and pestle to remove the testa. Otherwise, some clean sand may be added to aid the removal of the testa. The seeds are then put in a local sieve called "ajere" made of perforated calabash to wash it off in running water or in a large container of water. In Africa and Asia, the art of fermentation is widespread probably because people are well adapted to the indigenous organoleptic qualities of these food products than the industrial seasonings or foreign spices [6] [7] [11].

Fermented food condiments give pleasant aroma to soups, sauces and other prepared dishes worldwide, especially in most African countries and India where protein calorie malnutrition is a major problem [6] [12] [13]. Dawadawa is a typical condiment for flavouring of meals such as stew and soup made from soybean by the Hausa tribe in Nigeria that is similar to fermented locust beans (Parkia biglobosa). It is also valuable food condiment in West/Central Africa savannah region that constituted $1.4 \%$ of the daily calorie intake and $5 \%$ of the total protein intake [9] [14]. Oil seeds such as African locust bean, melon seed, castor oil seed, mesquite bean and soybean are also fermented to give condiments. Water samples used for "iru" processing were usually not pipe-borne water but mostly from some surface water sources, which can introduce contaminations into the peeled cotyledons. Similarly, The critical hazard points of public health importance in this study includes, feet used for dehulling the seed cotyledons, calabashes repeatedly used for fermentation, addition of salt in open places and wrapping leaves, Teak (Tectona grandis) leaves usually picked from the ground around the shedding trees for wrapping irú can serve as contaminants. Hence, the microbiological and food safety caution is necessary. Dehydration, salting and packaging of home produced food items such as locust beans (iru) in simple polyethylene bags is desirable to extend their shelf life. In this study various bacterial and fungal species associated with some locally fermented products in locust beans were isolated and identified. Moreover investigation on microbiological hazards associated with fermented locust beans was also intensified to safeguard the production of this food condiment meant for human consumption (Figure 1).

\section{Materials and Method}

\subsection{Sample Source}

The iru samples were collected in some major communities in Ondo State such as Akungba, Ikare, Supare, Okitipupa and Akure. The samples were transported to Microbiology laboratory of Adekunle Ajasin University Akungba-Akoko for further analysis.

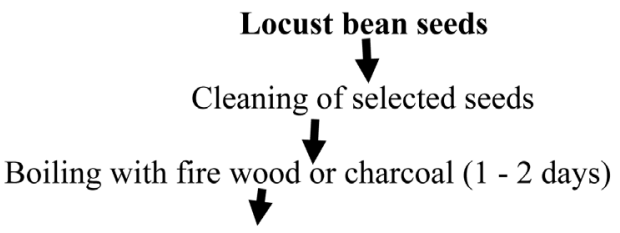

(Addition of nail/ wood ash or $0.1 \mathrm{M} \mathrm{Na}_{2} \mathrm{CO}_{3}$ to fasten boiling of the cotyled

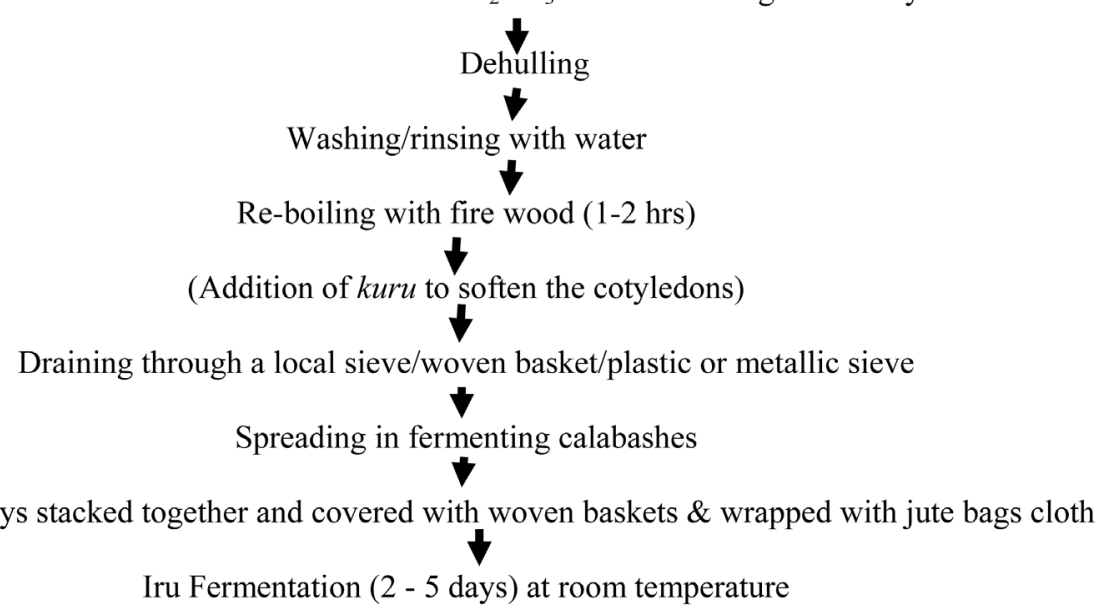

Figure 1. Flow chart for traditional preparation of irú condiment. 


\subsection{Isolation and Identification of Bacteria}

Serial dilution was carried out by weighing $1 \mathrm{gm}$ of iru into $10 \mathrm{~mL}$ of diluents water to form a stock culture. 1 $\mathrm{mL}$ of appropriate diluents was cultured in nutrient agar plates at $37^{\circ} \mathrm{C}$ for 24 hours. The bacterial populations of the locust bean samples were estimated from a pour plate technique. Stock cultures from this source were prepared in nutrient agar slants and then kept in the refrigerator at $4^{\circ} \mathrm{C}$ for further use. The bacterial isolates were identified by standard microbiological measures. The characterization of bacteria isolates were based on Gram staining, morphological and cultural characteristics coupled with relevant biochemical tests.

\subsection{Antibiotic Sensitivity Test}

The in vitro antibiotic susceptibility testing of bacterial isolates was performed using the standardized disc agar diffusion methods of the CLSI, [15] and Kaiser, [16]. The test was carried out by using an eighteen hours broth culture of each isolate incubated in test tube at $37^{\circ} \mathrm{C}$. After incubation, a sterile pipette was used to pick a suspension of the test organism in the test tube and was spread evenly across the plate containing Muller Hinton agar. A sterile forceps was used to place the antimicrobial disc between the medium and the culture incubated at $37^{\circ} \mathrm{C}$ for 18 hours. The test was read after checking that the bacterial growth for inhibition zones around the disc.

\section{Results}

This study helps to determine the microbiological quality of the fermented product, African locust bean (Parkia biglobosa) obtained from Ondo State, Nigeria. Table 1 shows the range of bacterial species that populates various forms of African locust bean (Parkia biglobosa). This ranged from $20 \times 10^{3} \mathrm{cfu} / \mathrm{g}$ to $200 \times 10^{3} \mathrm{cfu} / \mathrm{g}$ for total bacterial count, $3 \times 10^{3} \mathrm{cfu} / \mathrm{g}$ to $120 \times 10^{3} \mathrm{cfu} / \mathrm{g}$ for coliform count and $1 \times 10^{3} \mathrm{cfu} / \mathrm{g}$ to $60 \times 10^{3} \mathrm{cfu} / \mathrm{g}$ for the Lactobacillus spp. that normally populates MRS agar. Table 2 shows the changes in physical sensory parameters of fermented Parkia biglobosa. The changes in the physical sensory parameter of the fermented locust bean shows that the odour became more pleasant when fermentation process take place for longer days. It became slimy when fermentation continued at the day four. Various adverse changes in the qualities including the colour commences after 96 hours.

Table 3 shows the persistence of some common bacterial species such as Bacillus spp., Lueconostoc spp. and Staphylococcus spp. that populates the locus bean samples. The Lueconostoc spp. only survives till the second day of fermentation while others are still found after the seventh (7) day. Table 4 shows the cultural and biochemical characteristics of the bacterial isolates from African locust bean (Parkia biglobosa) for identification purposes. While in Table 5, the antibiotics susceptibility patterns of the bacterial species were determined.

Table 1. Heterotrophic bacterial count of fermented Parkia biglobosa.

\begin{tabular}{cccc}
\hline Sample code & Total bacterial count $\left(\mathrm{cfu} / \mathrm{g} \times 10^{3}\right)$ & Coliform count $\left(\mathrm{cfu} / \mathrm{g} \times 10^{3}\right)$ & MRS count $\left(\mathrm{cfu} / \mathrm{g} \times 10^{3}\right)$ \\
\hline A & 200 & 120 & 60 \\
B & 40 & 17 & 10 \\
C & 20 & 3 & 1 \\
\hline
\end{tabular}

Legend: A-African locust bean (Parkia biglobosa), Soft form “Iru pete”; B—Hard form “Iru woro”; C—Dried form “Iru gbigbe”.

Table 2. Changes in physical sensory parameters of fermented Parkia biglobosa.

\begin{tabular}{|c|c|c|c|c|c|}
\hline Days & Time (hours) & Texture & Odour & Colour & Slimness \\
\hline 1 & 24 & No change & Non-offensive & Creamy & Not slimy \\
\hline 2 & 48 & Partial change & Non-offensive & Creamy & Not slimy \\
\hline 3 & 72 & Partial change & Non-offensive & Creamy & Not slimy \\
\hline 4 & 96 & Changed & little-offensive & Deep creamy & Little slimy \\
\hline 5 & 120 & Changed & little-offensive & Deep creamy & More slimy \\
\hline 6 & 144 & Changed & Offensive & Brownish & More slimy \\
\hline 7 & 168 & Changed & Very-offensive & Deep brown & Very slimy \\
\hline
\end{tabular}


Table 3. Microorganisms isolated from locally and laboratory prepared Parkia biglobosa.

\begin{tabular}{cccccccc}
\hline & & & \multicolumn{2}{c}{ Days } \\
\hline Organisms & Locally produced Parkia biglobosa & Laboratory produced Parkia biglobosa & 1 & 2 & 3 & 4 & 6 \\
\hline Bacillus spp. & + & + & + & + & + & + & + \\
Lueconostoc spp. & + & + & + & - & - & - \\
Staphylococcus spp. & + & + & + & + & + \\
\hline
\end{tabular}

Legend: + Positive; - Negative.

Table 4. Cultural and biochemical characteristics of the bacterial isolates encountered in African locust bean samples.

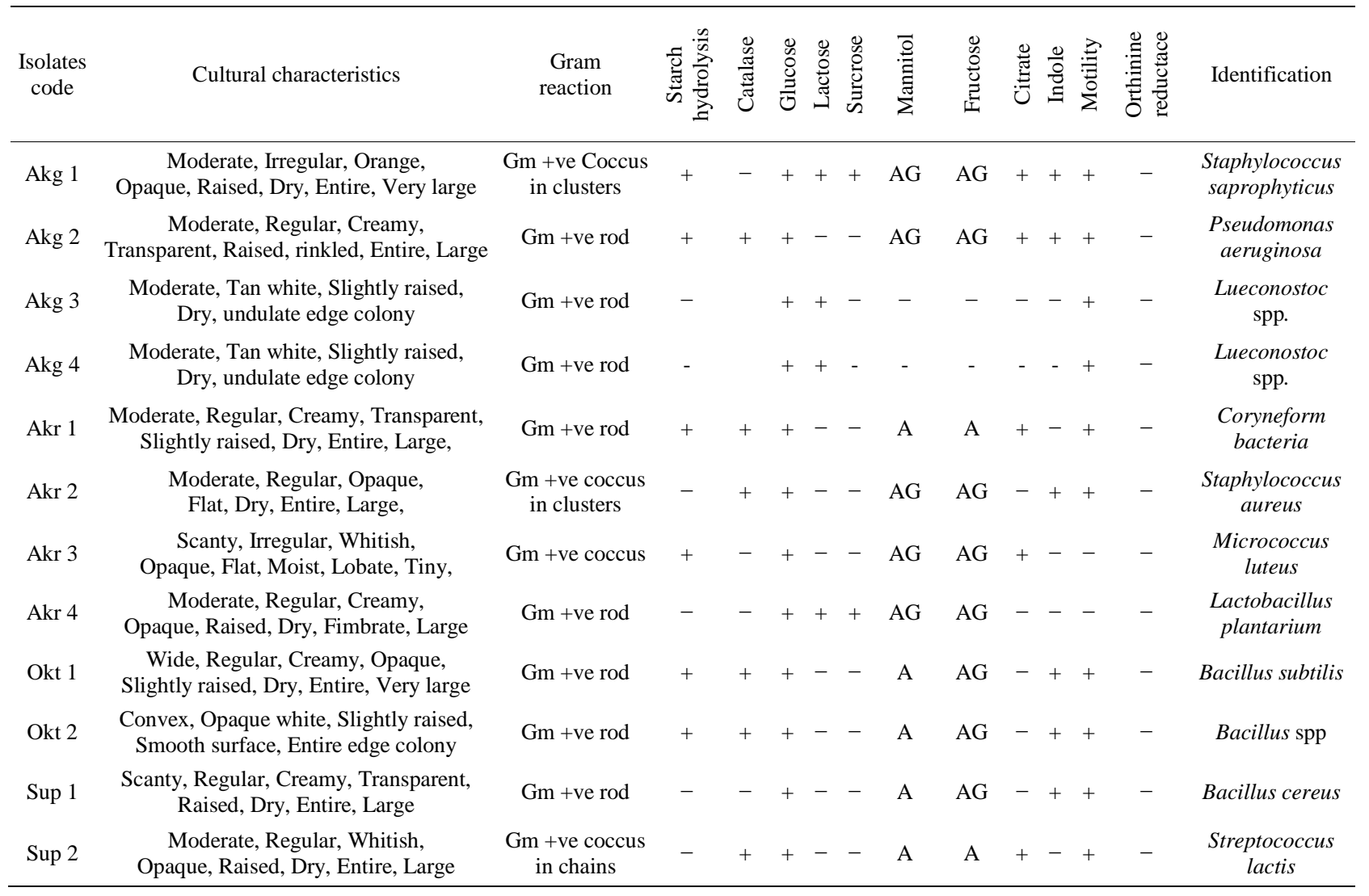

Legend: +, Positive; -, Negative; A, Acid; AG—Acid and Gas. Akg, Akungba; Akr, Akure; Sup, Supare; Okt, Okitipupa.

Table 5. Antibiotic sensitivity pattern of bacteria isolates (in mm).

\begin{tabular}{|c|c|c|c|c|c|c|c|c|c|c|c|c|c|c|}
\hline Lab code & Bacterial species & $\mathrm{AM}$ & СРX & SXT & $\mathrm{CH}$ & SP & $\mathrm{AU}$ & APX & $\mathrm{CN}$ & PEF & OFX & $\mathrm{R}$ & $S$ & $\mathrm{Z}$ \\
\hline Akg 1 & $\begin{array}{l}\text { Staphylococcus } \\
\text { saprophyticus }\end{array}$ & - & $11 \mathrm{R}$ & $12 \mathrm{R}$ & - & $25 S$ & - & - & - & - & $15 S$ & - & - & - \\
\hline Akg 2 & $\begin{array}{c}\text { Pseudomonas } \\
\text { aureginosa }\end{array}$ & - & $16 S$ & - & $14 \mathrm{R}$ & $12 \mathrm{R}$ & - & - & - & - & $12 \mathrm{R}$ & - & - & - \\
\hline Akr 1 & Coryneform bacteria & - & - & - & $14 \mathrm{R}$ & $20 \mathrm{~S}$ & - & - & $11 \mathrm{R}$ & $10 \mathrm{R}$ & $18 \mathrm{~S}$ & - & - & - \\
\hline Akr 2 & Staphylococcus aureus & - & $20 \mathrm{~S}$ & $13 \mathrm{R}$ & - & - & - & - & $15 S$ & $12 \mathrm{R}$ & - & - & - & - \\
\hline Akr 3 & Micrococcus luteus & - & $20 \mathrm{~S}$ & - & - & - & - & - & - & - & - & - & - & $12 \mathrm{R}$ \\
\hline Akr 4 & Lactobacillus spp & $18 \mathrm{~S}$ & - & - & $16 \mathrm{~S}$ & - & - & $20 \mathrm{~S}$ & - & - & - & - & - & - \\
\hline Okt 1 & Bacillus subtilis & - & $10 \mathrm{R}$ & - & - & - & - & - & $11 \mathrm{R}$ & - & - & - & $10 \mathrm{R}$ & - \\
\hline Sup 1 & Bacillus cereus & - & $18 \mathrm{~S}$ & - & - & - & - & $13 \mathrm{R}$ & - & - & - & - & - & - \\
\hline Sup 2 & Streptococcus lactis & - & $15 \mathrm{~S}$ & - & - & - & - & - & $10 \mathrm{R}$ & $20 \mathrm{~S}$ & - & - & - & - \\
\hline
\end{tabular}

Legend: S—Sensitive, R-resistant. 
Antibiotic used:

\begin{tabular}{|c|c|c|c|}
\hline \multicolumn{2}{|c|}{ High Profile Positive concentration } & \multicolumn{2}{|c|}{ High Profile Negative concentration } \\
\hline Amoxacillin (AM) & 30 ug & Amoxacillin (AM) & $30 \mathrm{ug}$ \\
\hline Ampiclox (APX) & 30 ug & Augmentin (AU) & 30 ug \\
\hline Ciprofloxacin (CPX) & $10 \mathrm{ug}$ & Chloranphenicol (CH) & $30 \mathrm{ug}$ \\
\hline Erythromycin (E) & $10 \mathrm{ug}$ & Ciprofloxacin (CPX) & $10 \mathrm{ug}$ \\
\hline Gentamycin (CN) & $10 \mathrm{ug}$ & Gentamycin (CN) & $10 \mathrm{ug}$ \\
\hline Pefloxacin (PEF) & $10 \mathrm{ug}$ & Pefloxacin (PEF) & $30 \mathrm{ug}$ \\
\hline Rocephin (R) & 25 ug & Septrin (SXT) & 30 ug \\
\hline Septrin (SXT) & $30 \mathrm{ug}$ & Sperfloxacin (SP) & $10 \mathrm{ug}$ \\
\hline Streptomycin (S) & $30 \mathrm{ug}$ & Streptomycin (S) & $30 \mathrm{ug}$ \\
\hline Zinnacef (Z) & $20 \mathrm{ug}$ & Tarivid (OFX) & $10 \mathrm{ug}$ \\
\hline
\end{tabular}

\section{Discussion}

This study shows various forms of bacterial and fungal species isolated from locust bean "Iru". Iru is a proteinrich fermented African soup condiment which is considered the most important food condiment in the entire west/central African savannah region. Its production is however basically by traditional, household level fermentation technology laden with food-borne hazards at virtually all points during processing as observed in the present study. The food condiment is however populated with some groups of bacteria (Table 1). Critical control points and possible food safety risks in the processing of African locust beans into iru were identified in this study. The locust beans seeds usually comes with a substantial microbial load comprising spores of aerobic spore-forming bacteria and mould spores most of which are drastically reduced during the prolonged boiling to soften the testa as obtainable in related fermentations [5] [7] [17]. Cooling of African locust bean, irú is normally done in the open air and this may introduce particulate and microbial contaminants coupled with the nature of local calabash and similar utensils used. Some changes in some physical sensory parameters (Table 2) may be as a result of this microbial activities and related environmental factors. It is expected that the longer the period of fermentation ( 4 - 5 days), the better the irú product, due to more activities of the fermenting bacterial flora but period of fermentation is another major difference in the method of traditional production of irú, in that now-adays, most of the fermentation times are usually one or three days for irú woro and irú pètè instead of three and five days respectively. The result obtained in this context corroborates with the study of Liman et al., [6] who demonstrated the impacts of some environmental conditions on quality of processed African locust bean.

Bacillus spp. which is a predominant organism obtained in this study together with some lactic acid bacteria like Lueconostoc spp. are capable of increasing the protein and fat contents of samples significantly (Table 3). This is consistent with the study of Ogbadu and Okagbue [7], which shows that various Bacillus species were responsible for the fermentation of African locust bean seeds. The presence and use of these groups of organisms as a starter culture for the product may be desirable because of their probiotics potential. However, the determination of some commonly used antibiotics against isolates from this sources which shows multiple antibiotic resistance (Table 4) is worrisome and hence the need to protect this condiment preparation under better hygienic processes. Previous reports [5] [6], shows that the presence of a high level of specific nutritive components in locust bean is an added advantage over seasoning salts. This study therefore helps to determine some major factors that can enhance qualitative production of African locust bean (Parkia biglobosa), 'iru', which is a beneficial nutritious food condiment.

\section{References}

[1] Oke, O.L. and Umoh, I.B. (1987) Lesser-Known, Oil Seed Chemical Composition. Nutrition Reports International, 17, 293-297.

[2] Achi, A.O. (2005) Traditional Fermented Protein Condiments in Nigeria. African Journal of Biotechnology, 4, 16121621.

[3] Esenwah, C.N. and Ikenebomeh, M.J. (2008) Processing Effects on the Nutritional and Anti-Nutritional Contents of African Locust Bean (Parkia biglobosa, Benth.) Seed. Pakistan Journal of Nutrition, 7, 214-217. http://dx.doi.org/10.3923/pjn.2008.214.217 
[4] Elemo, G.N, Elemo, B.O, Oladunmoye, O.O. and Erukainure, O.L. (2011) Comprehensive Investigation into the Nutritional Composition of Dehulled and Defatted African Locust Bean Seed (Parkia biglobosa). African Journal of Plant Science, 5, 291-295. http://www.academicjournals.org/ajps.

[5] Gernah, D.I., Atolagbe, M.O. and Echegwo, C.C. (2007) Nutritional Composition of the African Locust Bean (Parkia biglobosa) Fruit Pulp. Nigerian Food Journal, 25, 190-196.

[6] Liman, A.A., Egwin, P., Vunchi, M.A. and Ayansi, C. (2010) Lipase Activity in Fermented Oil Seeds of Africa Locust Bean, (Parkia biglobosa),Castor Seeds (Ricinu communis) and African Oil Bean (Pentaclethra macrophylla). Nigerian Journal of Basic and Applied Science, 18, 136-140. http://ajol.info/index.php/njbas/index

[7] Ogbadu, L.J. and Okagbue, R.N. (1988) Fermentation of African Locust Bean (Parkia biglobosa) Seeds: Involvement of Different Species of Bacillus. Food Microbiology, 5, 195-199. http://dx.doi.org/10.1016/0740-0020(88)90018-4

[8] Allagheny, N., Obanu, Z.A., Platt, G.C. and Owens, J.D. (1996) Control of Ammonia Formation during Bacillus subtilis Fermentation of Legumes. Food Microbiology, 29, 321-333. http://dx.doi.org/10.1016/0168-1605(95)00069-0

[9] Odunfa, S.A. (1985) Biochemical Changes in Fermenting African Locust Beans (Parkia biglobosa) during "iru” Fermentation. International Journal of Food Science \& Technology, 20, 295-303. http://dx.doi.org/10.1111/j.1365-2621.1985.tb00379.x

[10] Achi, O.K. (1992) Microorganisms Associated with Natural Fermentation of Prosopsis africana Seed for Production of Okpiye. Plant Foods Human and Nutrition, 42, 297-304. http://dx.doi.org/10.1007/BF02194090

[11] Sarkar, P.K., Jones, L.J., Craven, G.S., Somerset, S.M. and Palmer, C. (1997) Amino Acid Profiles of Kinema, a Soybean-Fermented Food. Food Chemistry, 59, 69-75. http://dx.doi.org/10.1016/S0308-8146(96)00118-5

[12] Sarkar, P.K., Cook, P.E. and Owens, J.D. (1993) Bacillus Fermentation of Soybeans. World Journal of Microbiology and Biotechnology, 9, 295-299. http://dx.doi.org/10.1007/BF00383066

[13] Enujiugha, V.N., Akanbi, C.T. and Adeniran, H.A. (2008) Evaluation of Starters for the Fermentation of African Oil Bean (Pentaclethra macrophylla Benth) Seeds. Nutrition \& Food Science, 38, 451-457. http://dx.doi.org/10.1108/00346650810906976

[14] Odunfa, S.A. (1986) Dawadawa in Legume Based Fermented Foods. Journal of Plant Foods, 6, 155-163.

[15] CLSI (2013) Update on the 2012-2013 CLSI Standards for Antimicrobial Susceptibility Testing: Edition-Susan Sharp. http://www.swacm.org/annualmeeting/2012/stlouisworkshops/WS4GPCLSIUpdate2012.pdf

[16] Kaiser, G. (2012) Kirby-Bauer Test (Online Manual, Lab 21). Syllabus—Department of Biology—Western Kentucky University. http://student.ccbcmd.edu/ gkaiser/index.html faculty.ccbcmd.edu/courses/bio141/labmanua/lab21/lab21.html

[17] Buchanan, R.L. (1995) The Role of Microbiological Criteria and Risk Assessment in HACCP. Food Microbiology, 12, 421-424. http://dx.doi.org/10.1016/S0740-0020(95)80124-3 